\title{
PROJETO URBANO SUSTENTÁVEL PARA A CIDADE DE ITU
} SUSTAINABLE URBAN PROJECT FOR ITU CITY, SP

\author{
Deize Sbarai Sanches Ximenes \\ Doutora em Arquitetura e Urbanismo - FAUUSP \\ E-mail: deizesanches@usp.br
}

\begin{abstract}
RESUMO
Este artigo é fruto de uma pesquisa de doutorado da FAUUSP, desenvolvida na cidade de Itu - interior oeste de São Paulo, a qual teve uma expansão desordenada e uma dispersão urbana vinculada à especulação imobiliária e ao uso inadequado dos recursos naturais. Novos cenários foram propostos para o desenvolvimento de um projeto urbano sustentável para Itu, criando uma conexão entre o Centro Velho e o Novo Centro, a partir de três eixos estruturadores: ecológico, cultural e hídrico, por meio de uma mobilidade sustentável e um ordenamento territorial do Centro Histórico. A intenção é promover uma melhor qualidade de vida urbana, uma valorização e apropriação das áreas verdes e dos conjuntos arquitetônicos de importância histórica, para uso público, e a preservação e o uso racional dos recursos naturais disponíveis no meio urbano.
\end{abstract}

Palavras-chave: Projeto urbano sustentável; Cidade de Itu; estrutura ecológica; estrutura cultural; estrutura hídrica.

\section{ABSTRACT}

This article is the result of a Ph.D. research at FAUUSP, developed in Itú City, in the countryside of São Paulo State, which had a disorderly expansion and an urban dispersion linked to real estate speculation and the inadequate use of natural resources. New scenarios were proposed for the development of a sustainable urban project for that city, creating a connection between the Old Downtown and the New Downtown, by the application of three structuring axes: ecological, cultural and hydrological, through a sustainable mobility and a territorial planning for the Historic Center. The aim is to promote a better quality of urban life, the improvement and appropriation of green are- 
as and architectural ensembles of historical importance for public use, as well as the preservation and rational use of natural resources available in the urban area.

Keywords: Sustainable Urban Design; Itú City; Ecological Structure Cultural Structure; Water Structure.

\section{INTRODUÇÃO}

O desenvolvimento das atividades econômicas de Itu e o rápido crescimento da população acarretaram um processo de expansão urbana desordenada e dispersa, a perda da cobertura vegetal e o uso inadequado dos recursos naturais. Este panorama geral, analisado durante a pesquisa, trouxe como objetivo propor diretrizes para um projeto urbano sustentável para a cidade de Itu, conectando o Centro Velho com o Novo Centro, por meio de uma mobilidade sustentável, e criando novos cenários para o desenvolvimento de um Novo Centro planejado a partir de três eixos estruturadores: cultural, ecológico e hídrico, e de um ordenamento territorial do Centro Histórico.

A cidade de Itu se iniciou em 1610 com a construção de uma capela erguida por Domingos Fernandes sob a invocação de Nossa Senhora da Candelária. O povoado se formou ao lado desta capela - que se tornaria sua Igreja Matriz.

A partir do final do século XIX, percebe-se uma notável modificação na morfologia urbana do centro de Itu; as ruas passaram a se estender longitudinalmente por todo o espigão da colina onde se deu a ocupação inicial e as formas da paisagem foram profundamente alteradas. Para esse processo, foi de grande importância a implantação do ramal ferroviário, inaugurado em 1873. Desse modo, um ano antes, a Rua do Comércio, atual Floriano Peixoto, já era prolongada até o Largo da Estação, atual Praça Gaspar Ricardo (REIS, 2001).

O século XX representou o início de uma nova era, com as primeiras indústrias, sobretudo têxteis, que necessitavam de recursos hídricos para gerar energia a vapor, como a Fábrica de Fiação e Tecelagem São Luiz em Itu. A existência de cachoeiras e rios em abundância no município fez com que as novas fábricas pudessem aí se instalar e utilizar o potencial hídrico da região. $O$ centro de Itu se volta, então, às atividades terciárias devido ao forte processo de industrialização e o surgimento dos principais 
eixos de escoamento das mercadorias; as rodovias Castelo Branco e Santos Dumont (Antiga Rodovia do Açúcar), a proximidade do aeroporto internacional de cargas Viracopos em Campinas, e o acesso rodoviário e ferroviário ao porto de Santos.

Segundo Santos (2004), a presença dessas inovações no território torna-se critério de definição da localização das empresas, visto que sua mudança só é viável quando acompanhada do acesso às redes. Como a produção das condições materiais que permitem a formação dessas redes no território é bastante limitada, ela impõe limites à dispersão dos estabelecimentos econômicos, sobretudo das indústrias.

O processo de crescimento da metrópole e da região de Itu, atrelado ao crescimento industrial, contribuiu para a valorização da especulação imobiliária, acarretando alterações na estrutura da cidade; o êxodo rural vinculado ao aumento das atividades terciárias, as facilidades de crédito, o aumento do consumo e a popularização do centro. A população com renda mais alta, que habitava esta área, adota novos padrões de moradia; os condomínios e loteamentos fechados horizontais, que se implantaram ao redor da cidade a partir de meados da década de 1970 (AJONAS, 2009), colaboraram para a preservação do patrimônio histórico, impedindo a verticalização do mesmo.

Atualmente, o Centro Histórico possui uma alta concentração populacional, necessitando de uma reestruturação urbana e uma valorização dos bens tombados, assim como o fortalecimento e a integração com o Novo Centro a partir de iniciativas sustentáveis.

\section{LOCALIZAÇÃO DO CENTRO HISTÓRICO E NOVO CENTRO}

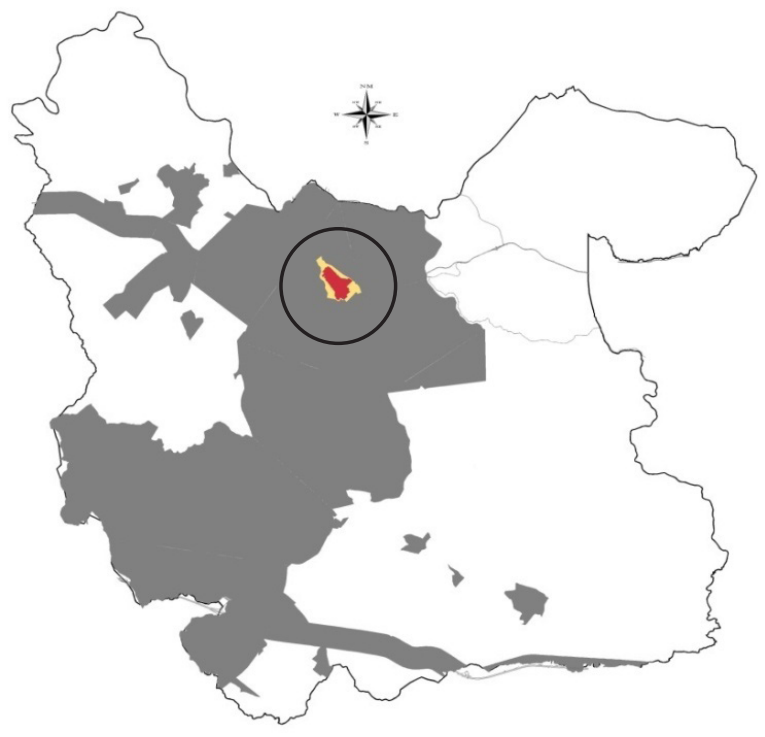

O centro Histórico de Itu está localizado no norte do Município, numa área total de $1.862 \mathrm{~km}^{2}$, sendo $944 \mathrm{mil} \mathrm{m}^{2}$ referente à Zona Histórica e $918 \mathrm{mil} \mathrm{m}^{2}$ à Zona de Preservação Histórica, com altitudes que variam entre 566 e 600 metros, numa colina (Figura 01).

Figura 01 - Localização do Centro

Histórico de Itu, s/escala

Fonte: Elaborado pela autora, 2017 
A malha do Centro Histórico é constituída por uma rede de ruas em formato de tabuleiro, com cerca de 50 quadras, com uso predominantemente comercial, e algumas residências, museus e igrejas que ocupam edificações tombadas. No seu entorno temos algumas vias principais; como a Avenida Dr. Otaviano Pereira Mendes, por onde corre o Córrego Taboão, a Avenida Dr. Ermelindo Maffei, que contorna a área do Regimento Militar Deodoro e dá acesso ao Plaza Shopping Itu, a Rua dos Andradas, que passa a se chamar Rodovia Waldomiro Corrêa de Camargo após cruzar o centro sentido São Paulo e Sorocaba (SP-079) e a Avenida Galileu Bicudo, nomeada SP-079.

A implantação do Bairro Itu Novo Centro (Figura 02) foi em 2006, numa antiga área do Regimento Militar Deodoro de artilharia montada, distante apenas $1 \mathrm{~km}$ do Centro. A meta era incentivar o comércio e o desenvolvimento econômico, visto que o centro da cidade, já tombado, não comportava mais o crescimento do município. A proposta inicial desta área era utilizá-la como APA - Área de Proteção Ambiental, fazer o plantio de mudas e criar um parque ecológico de 48 mil m², mas a União; proprietária das terras, não aceitou e a área foi desmatada, loteada e denominada Itu Novo Centro.

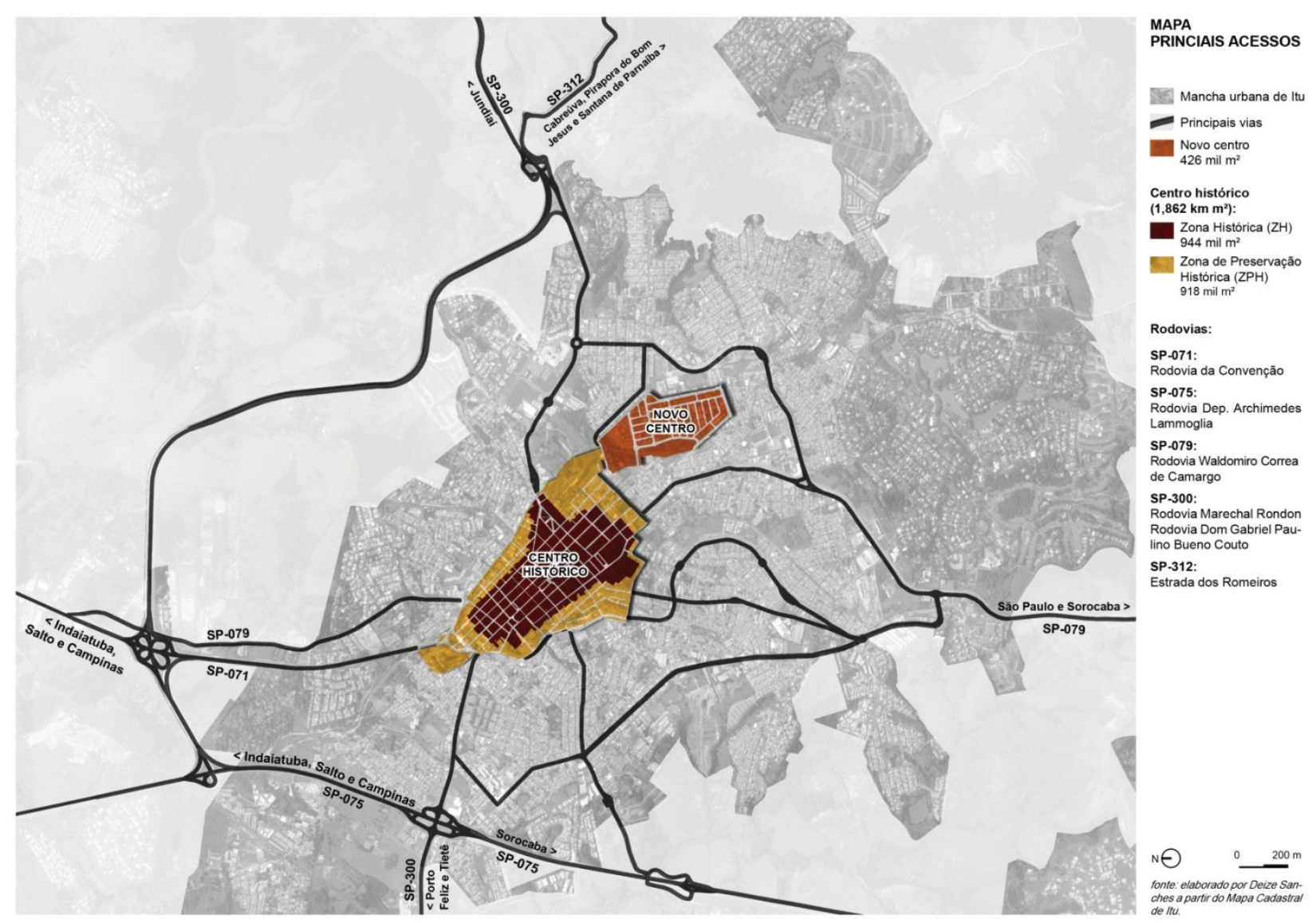

Figura 02 - Mapa de localização do Centro Histórico e Novo Centro. Fonte: Elaborado pela autora, 2017 
Atualmente, abrange uma área de $426 \mathrm{mil} \mathrm{m}^{2}$, com infraestrutura básica, dividida em 209 mil m$^{2}$ de lotes em 23 quadras, entre residenciais e comerciais, na sua maioria sem construção; 115 mil $\mathrm{m}^{2}$ de sistema viário; 55 mil $\mathrm{m}^{2}$ de áreas institucionais, já contabilizando a nova sede da Prefeitura de Itu e $47 \mathrm{mil} \mathrm{m}^{2}$ de espaços livres, entre eles, a faixa de proteção permanente do Córrego Taboão; onde se encontra o Parque Ecológico Taboão e a Secretaria do Meio Ambiente.

O acesso ao Centro Histórico e ao Novo Centro se faz pelas rodovias: ao norte - (SP 071) Rodovia da Convenção acesso à Campinas e Salto, (SP 079) Rodovia Waldomiro Correa de Camargo acesso à Indaiatuba, Salto e Campinas, e a (SP 300) Rodovia Marechal Rondon acesso à Porto Feliz e Tietê; à leste - (SP 300) Rodovia Dom Gabriel Paulino Bueno Couto com acesso à Jundiaí e a (SP 312) Estrada dos Romeiros acesso à Cabreuva, Pirapora do Bom Jesus e Santana de Parnaíba; à oeste - (SP 300) Rodovia Dom Gabriel Paulino Bueno Couto acesso à Porto Feliz e Tietê; e ao sul - (SP 079) Rodovia Waldomiro Correa de Camargo sentido São Paulo e Sorocaba (Figura 02)

\section{PROJETO URBANO SUSTENTÁVEL - DIRETRIZES E DESENHOS ESQUEMÁTICOS}

As diretrizes de Projeto Urbano Sustentável para a cidade de Itu - Ligação Centro Histórico e o Novo Centro foram desenvolvidas a partir dos eixos estruturadores: ecológico, hídrico e cultural, da mobilidade sustentável e do Plano Diretor, criando assim, novos cenários para um Projeto Urbano Sustentável:

- Estrutura Ecológica (EE): malha verde que identifica as APAs (Áreas de Proteção Ambientais), as APPs (Áreas de Proteção Permanente), os parques, as praças e as áreas verdes residuais, mostrando sua importância na resiliência urbana ambiental e a necessidade de manutenção e preservação da vegetação nativa. A estrutura ecológica desenvolvida no eixo de ligação entre o Centro Histórico e o Novo Centro, irá conectar os diversos fragmentos e manchas verdes existentes, e propor novas manchas e corredores verdes de ligação entre esses elementos isolados, criando uma rede sustentável.

- Estrutura Hídrica (EH): malha azul que identificada os canais de água, as lagoas naturais e os demais corpos hídricos. Os córregos e rios devem ser abertos para manter o ciclo hidrológico, sem alterar suas características 
naturais, devolvendo à paisagem urbana este elemento fundamental para a drenagem das águas das chuvas. Esta estrutura fomentará espaços de lazer ao longo das APAs dos córregos Brochado e Taboão, identificará os pontos de alagamento e deve propor novos cenários com o uso de tipologias da infraestrutura verde, possibilitando a integração dos cursos de água com o espaço urbano de forma sustentável.

- Estrutura Cultural (EC): malha marrom que identifica a riqueza produzida pelo Homem ao longo dos anos, como o patrimônio cultural da cidade, as afetividades e envolvimentos da comunidade com a cultura local de valor histórico, as inúmeras igrejas de estilo colonial, museus e monumentos arquitetônicos, as fazendas históricas, os roteiros turísticos dos Bandeirantes e Caminho do Sol, o Núcleo Pedregulho, e o Parque Geológico do Varvito.

Todo esse potencial irá contribuir para aproximar a comunidade dos processos naturais produtivos, criando a oportunidade de reinserção social de grupos desenraizados. A pulverização da riqueza e da cultura instalada no Centro Histórico para bairros vizinhos (como o Itu Novo Centro, assim como para o turismo regional) irá mostrar a identidade ali produzida ao longo dos anos.

As duas áreas possuem características bem marcantes e distintas. Por um lado, um centro totalmente saturado com uma grande concentração de comércios e serviços, e um alto grau de conjuntos arquitetônicos de valor histórico, sem sua real valorização. Por outro, um bairro totalmente novo, em processo de desenvolvimento, necessitando de um planejamento sustentável, uma adequação ao entorno já consolidado e um desenho urbano compatível com a necessidade local.

\section{DIRETRIZES - ESTRUTURA ECOLÓGICA (DTEE) - (Ver Figura 10)}

\section{- Instalação do Itu Parque Linear - 7.360 metros (Figura 03)}

Ao longo dos Córregos Brochado (3.860 metros) e Taboão (3.500 metros); nas áreas de Proteção Permanente (APPs) - numa faixa de no máximo 30 metros, será implantado um corredor verde, formalizando um Parque Linear de 7.360 metros, aproximadamente 22 ha para uso de pedestres e ciclistas, com diferentes espaços de lazer e estar com infraestrutura de apoio ao usuário (bancos, mesas, iluminação, lixeiras, pergolados, play- 
ground). Este parque foi proposto com a intenção de criar diversas conexões e integrações para a cidade de Itu; como por exemplo: a integração entre os bairros vizinhos à área central, facilitando a mobilidade urbana; a configuração de um corredor ecológico permitindo a passagem de animais, o deslocamento de sementes e o aumento da cobertura vegetal; a conectividade do parque linear com as demais manchas verdes - o Parque Ecológico do Taboão, localizado no Bairro Novo Centro, o Parque Central Propositivo e os fragmentos arbóreos ao longo dos córregos. Outro importante fator é a devolução dos canais de água para a paisagem urbana e para o uso público de forma convidativa.

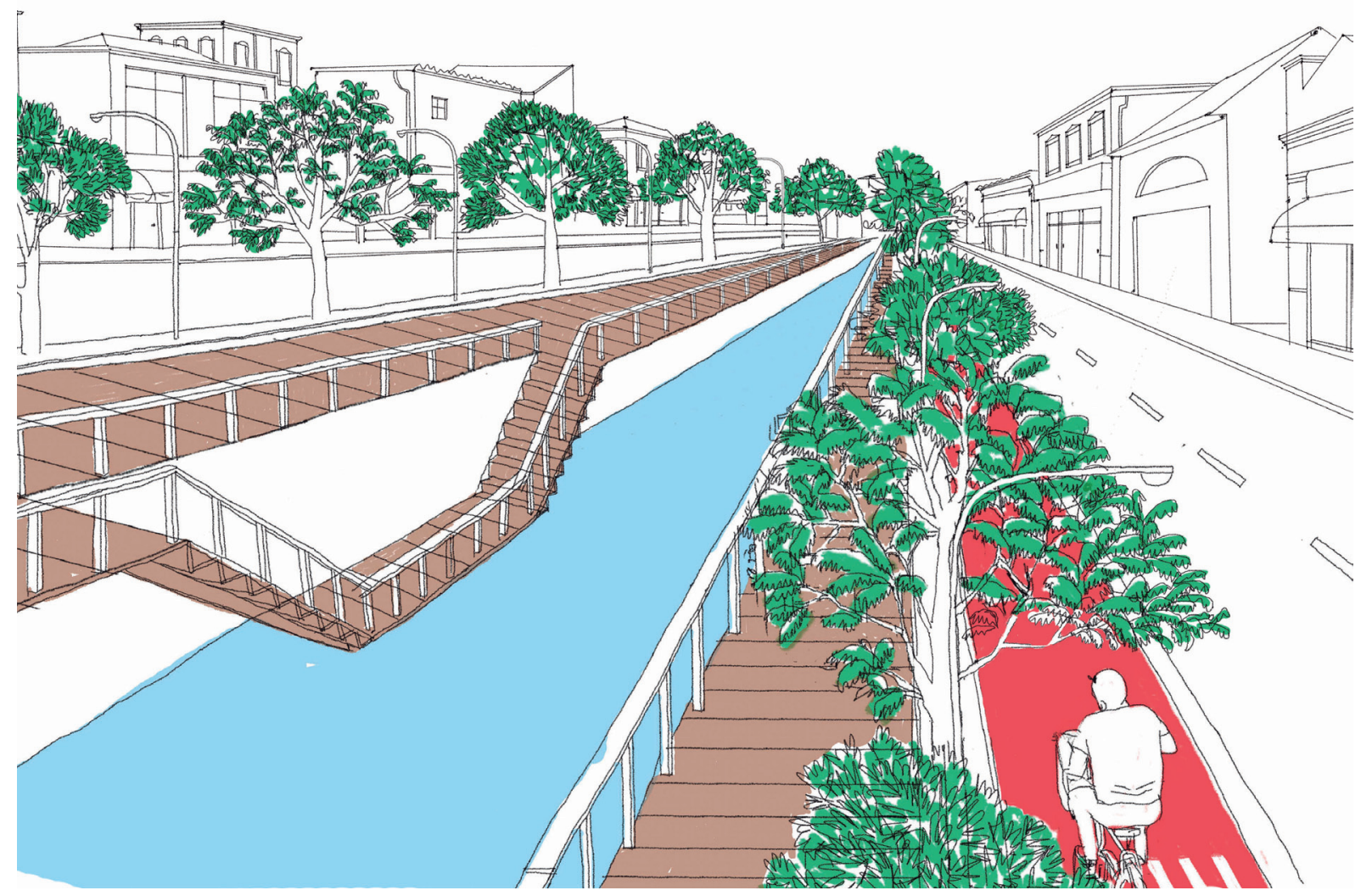

Figura 03 - Desenho esquemático do Parque Linear - Avenida Dr. Otaviano Pereira Mendes Fonte: Elaborado pela autora, ilustração de Bruna Ximenes, 2017

- Instalação do Parque Central de Itu (Figura 04)

A área verde do Regimento Militar Deodoro $\left(260 \mathrm{~km}^{2}\right)$, definida basicamente como Zona Exclusivamente Residencial 2, terá seu uso alterado para Zona de Preservação Ambiental (ZPA), desenvolvendo nesta área o "Parque Central de Itu". O objetivo é criar um novo espaço de lazer e integração da sociedade e garantir melhores 
condições ambientais na área central. O parque estará diretamente conectado ao "Itu Parque Linear" por estar localizado à margem do Córrego Taboão e terá fácil acesso tanto à nível de transporte público como de mobilidade alternativa, pois estará na Avenida Ermelindo Maffei, uma das principais vias centrais que liga às rodovias de acesso à Jundiaí (SP 300) e à Cabreúva, Pirapora do Bom Jesus e Santana de Parnaíba (SP 312), conhecida por Estrada dos Romeiros.

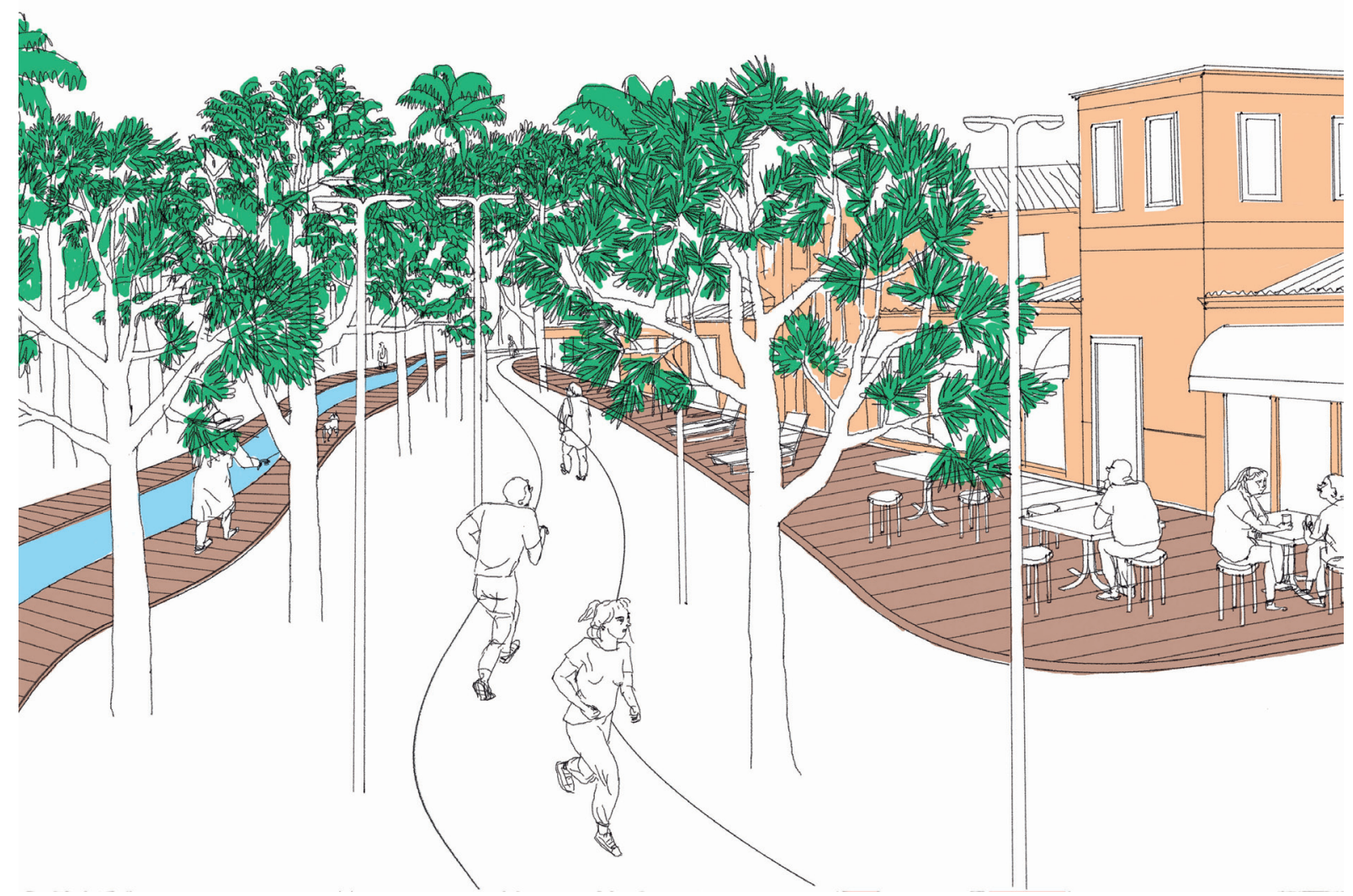

Figura 04 - Desenho esquemático do Parque Central.

Fonte: Elaborado pela autora, ilustração de Bruna Ximenes, 2017

\section{- Inserção de Mata Nativa no Parque Central de Itu e no Parque Linear}

A cobertura vegetal natural predominante em Itu é a Mata Atlântica ou Mata Latifoliada Tropical, grande parte devastada pela intensa produção agrícola ao longo do tempo, ora pela cultura do café, ora pela de cana-de-açúcar (TROPPMAIR, 2004). A intenção desta diretriz propositiva é a recuperação desta cobertura vegetal, nas áreas do Parque Linear e do Parque Central. 


\section{- Hortas urbanas comunitárias}

A implantação de hortas urbanas comunitárias nas manchas verdes centrais de Itu Parque Linear / Parque Central / Parque Ecológico do Taboão e áreas residuais irá colaborar para a integração da comunidade e a educação ambiental; o saber se apropriar do espaço público para uma função coletiva em prol de todos.

\section{- Instalação das Ruas Verdes (Figura 05)}

Será proposta uma malha verde nas ruas do Centro Histórico e nas principais avenidas do Bairro Novo Centro, colaborando com a rede cultural e proporcionando melhores condições ambientais para os pedestres realizarem seus percursos diários entre trabalho e moradia, assim como, os trajetos referentes aos circuitos históricos de museus, igrejas e o conjunto arquitetônico como um todo, tornando agradável o ir e vir entre bairros e o caminhar pelas calçadas arborizadas.

As áreas verdes ao longo das calçadas terão a função de drenagem natural, com a implantação das biovaletas e a captação e reutilização das águas pluviais para usos urbanos; como lavagem de ruas, irrigação de canteiros e áreas verdes públicas e limpeza das fachadas de monumentos históricos - igrejas, museus.



Figura 05 - Desenho esquemático das Ruas Verdes / Rua Barão do Itaim - Centro Fonte: Elaborado pela autora, ilustração de Bruna Ximenes, 2017 
Será necessário analisar caso a caso as dimensões dos passeios públicos e do leito carroçável, para que a proposta seja executada sem problemas de acessibilidade. Poderá ser dimensionada uma calçada com 2,20 metros de largura e uma ciclovia de 1,50 metros, mantendo a outra calçada com a dimensão original, que hoje tem uma variação entre 1,50 e 2,20 metros (Figura 06).

A Rua Paula Souza - eixo 1 de ligação do Novo Centro com o Centro Histórico ganhará a função de corredor ecológico e cultural, promovendo as ruas verdes ${ }^{1}$ com o plantio de árvores nativas que farão a integração das praças centrais da via Paula Souza de 3 km de extensão com as Áreas de Proteção Permanente dos Córregos Brochado e Taboão; e a conexão com as edificações de valor histórico e arquitetônico do Centro Histórico, de acordo com os desenhos esquemáticos propositivos (Figura 07).

Figura 07 - Planta e Corte esquemático da Rua Paula Souza - Eixo Cultural (esquerda). Fonte: Elaborado pela autora, 2017

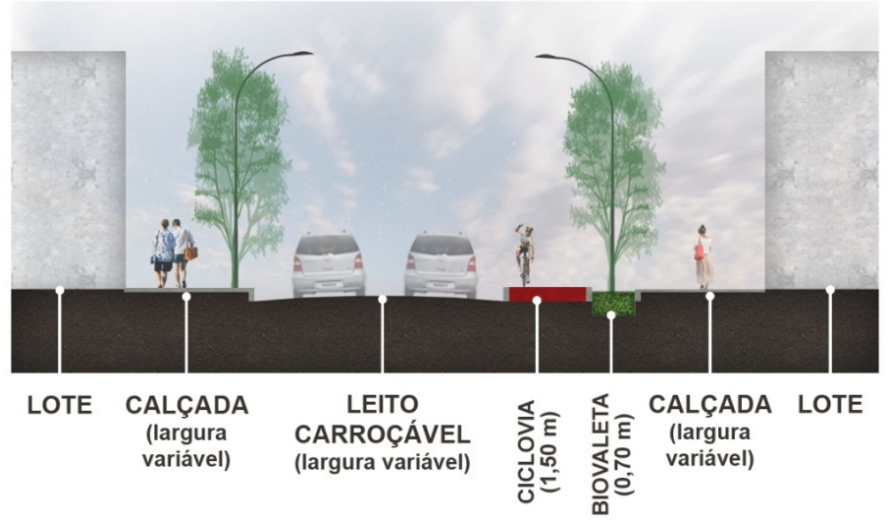

Figura 06 - Corte esquemático propositivo das Ruas Verdes. Fonte: Elaborado pela autora, 2017
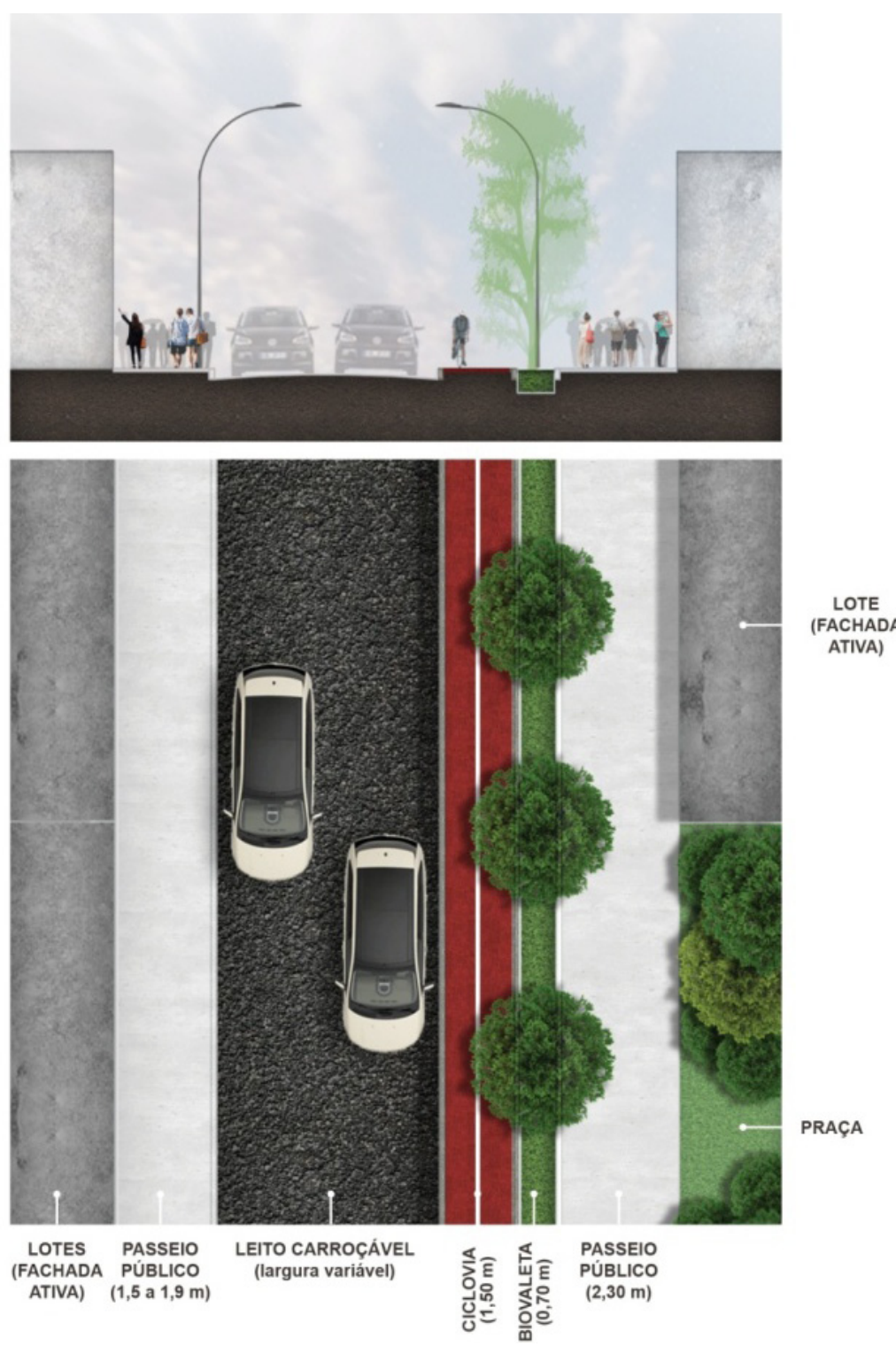

\footnotetext{
${ }^{1}$ Ruas Verdes são ruas cuja principal característica é a arborização intensa, de preferência nativa, trazendo diversos benefícios aos espaços urbanos.
} 

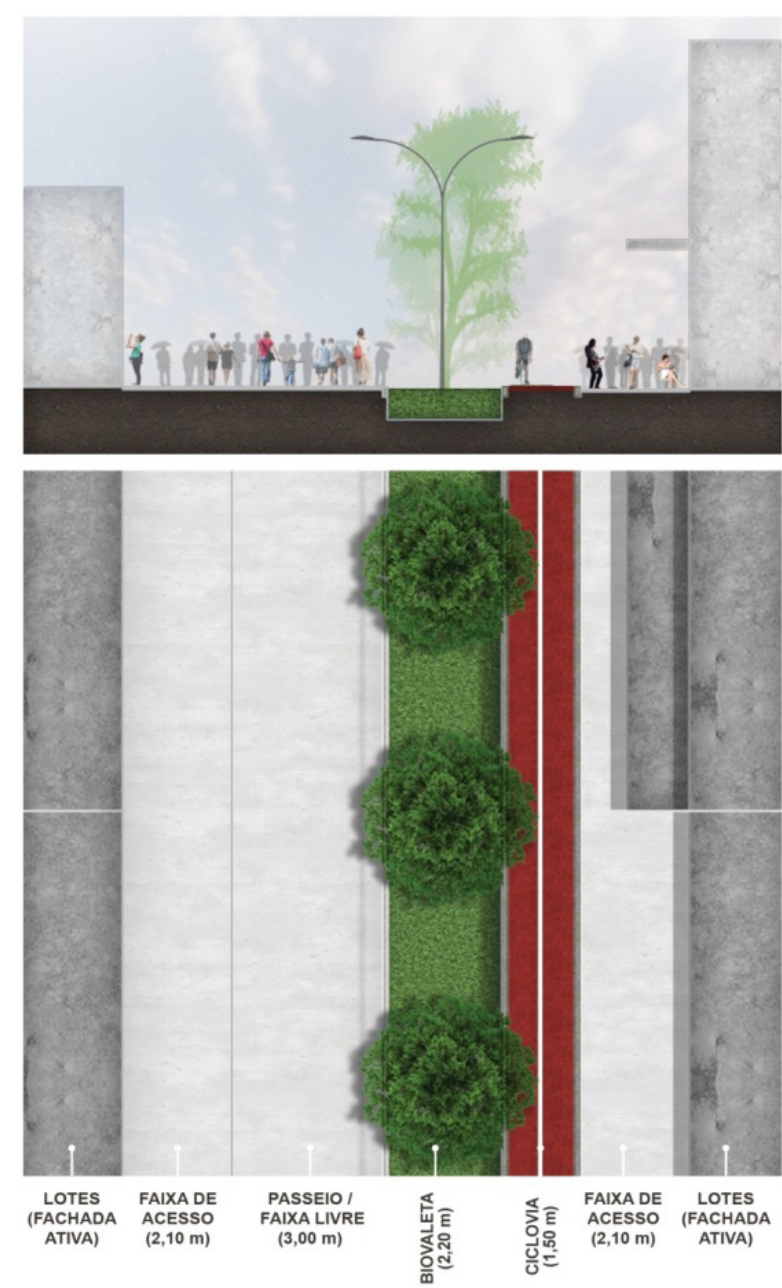

Figura 08 - Planta e Corte da Rua Floriano Peixoto - Eixo Comercial (direita).

Fonte: Elaborado pela autora, 2017
A outra ligação a promover as ruas verdes será o eixo 02 - Rua Floriano Peixoto de 2,4 km de extensão que irá ligar a Antiga Estação Ferroviária Ituana, o Itu Parque Linear e o Bairro Itu Novo Centro, alimentando uma conexão de âmbito social, econômico e turístico, visando o crescimento do comércio para o Novo Bairro, conforme desenhos esquemáticos propositivos (Figura 08).

\section{DIRETRIZES - ESTRUTURA HÍDRICA (DTEH) - (Ver Figura 10)}

\section{- Instalação de Lagoas Pluviais}

(Figura 09)

A canalização do curso de água dos Córregos Taboão e Brochado apenas transfere o problema para jusante, não solucionando as inundações de forma definitiva, assim como a construção dos atuais piscinões - Vila Gatti e Jardim Faculdade, ambos proporcionando mais área impermeável para o centro.

O novo cenário tem como proposta a construção de Lagoas Pluviais ${ }^{2}$ em áreas de alto risco; nos pontos de inundação demarcados ao longo dos córregos, nos dois piscinões e nas cinco lagoas existentes na área do Regimento Deodoro. A água da chuva poderá ser armazenada nas Lagoas Pluviais e reutilizada nas áreas urbanas;

\footnotetext{
${ }^{2}$ A Lagoa Pluvial funciona como uma bacia de retenção integrada ao sistema de drenagem destinada a acomodar o excesso de água das chuvas e evitar as inundações. Constitui numa lagoa onde a capacidade de água é superior ao volume de água permanente, onde a capacidade de armazenamento é o volume entre o nível permanente de água e o nível de transbordamento (HERZOG, 2013)
} 


\section{- Instalação de decks (Figura 09)}

Os canais de estiagem do Córrego Brochado e Taboão deverão ser recalculados conforme sua vazão natural e os leitos dos rios deverão ser divididos em dois; leito menor e leito maior com diferentes usos durante o período de estiagem, com deques de permanência incentivando o convívio público e a apreciação do curso da água, principalmente nas áreas do Parque Central e nos percursos isolados junto às avenidas Galileu Bicudo e Dr. Otaviano Mendes;



Figura 09 - Desenho ilustrativo da Avenida Galileu Bicudo - Lagoa Pluvial Fonte: Elaborado pela autora, ilustração de Bruna Ximenes, 2017

Visando a ampliação do sistema de drenagem do Centro Histórico, será proposta a implantação de biovaletas ${ }^{3}$ - uma tipologia da infraestrutura verde de drenagem natural em trechos das ruas verdes (novo cenário), beneficiando-se da declividade natural do terreno em direção aos córregos Brochado e Taboão, e promovendo a captação da água da chuva e o reuso para rega dos canteiros, lavagem das vias, entre outros.

\footnotetext{
3 Tipologia da Infraestrutura verde. São jardins lineares, em cotas mais baixas, ao longo de vias e estacionamentos que permite a captação da água das chuvas, a purificação e o armazenamento (Herzog, 2013)
} 


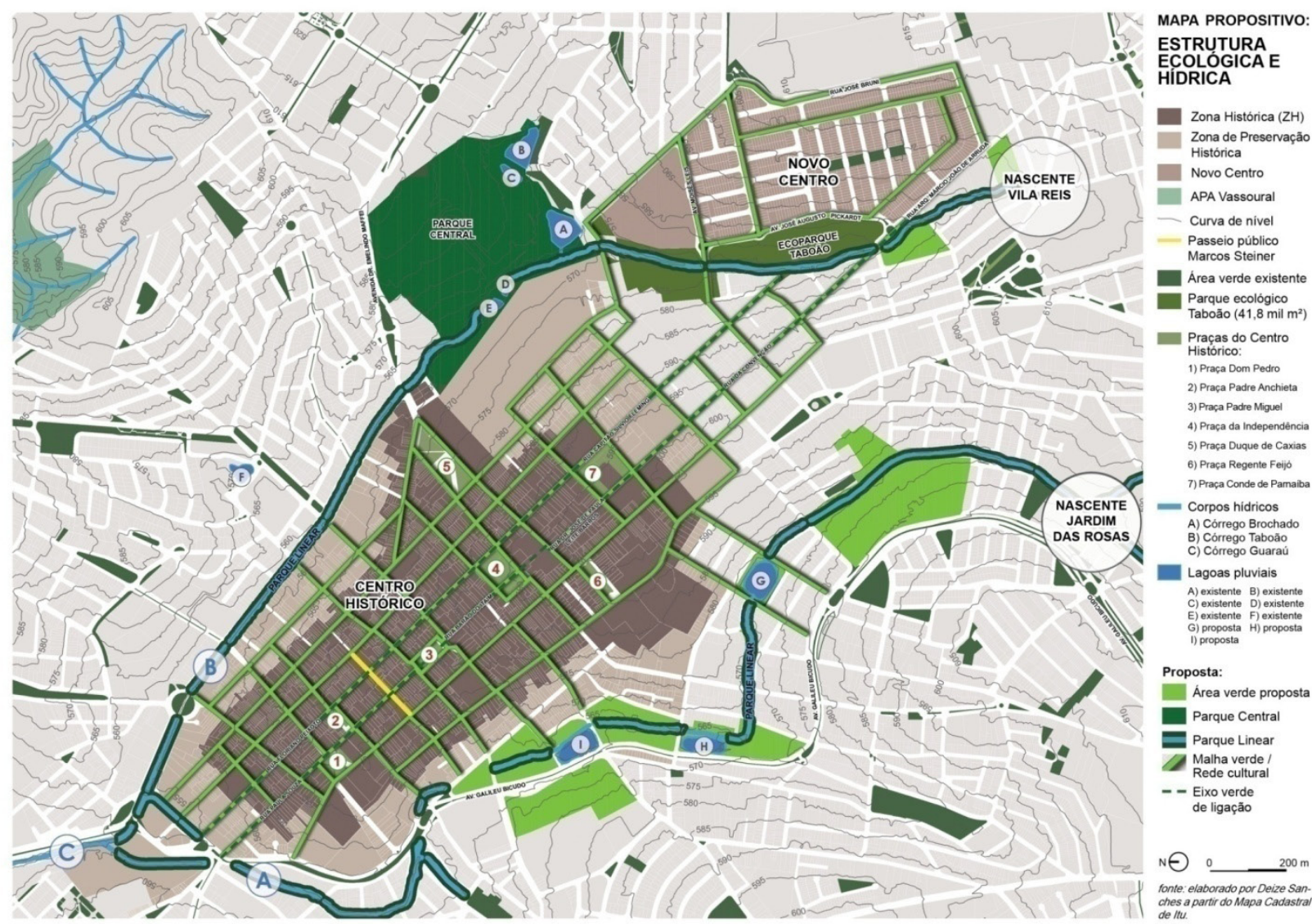

Figura 10 - Mapa propositivo - Estrutura Ecológica e Hídrica. Fonte: Elaborado pela autora, 2017

\section{DIRETRIZES - ESTRUTURA CULTURAL (DTEC) - (Ver Figura 11)}

\section{- Instalação da Rede Cultural}

A rede cultural será formatada pelos principais eixos viários de acesso aos núcleos culturais e pelas ruas históricas centrais, interligas pelo Itu Parque Linear, que irá contornar a Área de Preservação Histórica. Os principais pontos de interesse cultural e histórico ao longo dos eixos viários são: Antiga Estação Ferroviária Ituana, localizada ao norte do eixo comercial; Núcleo Pedregulho: acesso pela Rodovia Marechal Rondon (SP 300) - sentido Tietê, e Rodovia Dom Gabriel Bueno Couto (SP 300) - sentido Jundiaí; Parque Geológico do Varvito; Roteiros Turísticos dos Bandeirantes e Caminho do Sol, com um trecho de Estrada Parque entre Itu e Cabreuva; Fazendas e chácaras de valor histórico no perímetro urbano com acesso pela Rodovia da Convenção (SP071) e Rodovia Waldomiro Correa de Camargo (SP 079) - sentido Salto e Campinas. 


\section{- Criação de Rotas Turísticas}

A instalação da Rede Cultural possibilita a criação de diferentes rotas turísticas, tendo como marco zero a Antiga Estação Ferroviária Ituana, que sediaria o Centro de Informações Turísticas com material detalhado sobre os roteiros e monitores experientes para realizar passeios guiados. As rotas seguiriam para o centro histórico, para as fazendas históricas, para o Núcleo Pedregulho e para o Roteiro dos Bandeirantes e Caminho do Sol.

\section{- Renovação das edificações tombadas}

A maioria dos imóveis no eixo histórico da Rua Paula Souza, como museus e igrejas, está necessitando de conservação e manutenção; muitos deles estão subutilizados e sem uma preservação adequada. São necessários incentivos fiscais do poder público para renovação destas edificações, assim como novos usos públicos;

\section{- Novo uso à Antiga Estação Ferroviária Ituana}

A antiga Estação Ferroviária Ituana terá como novo cenário proposto, um Museu da História da Companhia Ytuana da Estrada de Ferro, um Centro de Informações Turísticas e passeios turísticos de trem para uma renovação de uso, em monumentos de valor histórico subutilizados;

\section{- Implantação do Centro de Oficinas}

De acordo com a Operação Urbana Centro Histórico, é importante a criação de um estoque construtivo com possibilidade de ser transferido para outras áreas da cidade, garantindo a participação da comunidade na identificação, valorização, preservação e conservação dos elementos significativos da paisagem urbana e fiscalizando o Centro Histórico de forma diferenciada do restante do território urbano de Itu. Assim, teremos a implantação de um Centro de Oficinas no Bairro Itu Novo Centro, no eixo cultural, tendo como objetivo a valorização da identidade e do patrimônio cultural e artístico e a participação mais efetiva da população;

\section{- Museu à céu aberto}

Dar nova identidade às áreas verdes, levando a cultura local até os parques propostos, para ser apreciada pela comunidade e pelos turistas regionais, com a proposta de inserção de atividades culturais: pinturas, esculturas, rodas de músicas tradicionais, exposições de obras de arte e demais atividades à céu aberto; 
- Restauração de Pontos Históricos

É essencial a restauração do Mercado Municipal, que hoje se encontra em estado precário de manutenção e conservação, sem o incentivo financeiro do PAC. De acordo com os levantamentos realizados no Centro Histórico, as edificações tombadas, com uso voltado para o público em geral, deverão ter seus imóveis restaurados com incentivos fiscais dos órgãos públicos, como isenção de impostos.

\section{- Instalação do Projeto Educação Ambiental}

A educação ambiental será desenvolvida com o incentivo de órgãos públicos em parceria com os órgãos privados, produzindo material didático de conscientização da população, a respeito do valor do patrimônio ambiental, histórico, arquitetônico e cultural que a cidade dispõe;

\section{- Instalação Rede Regional de Interesses Comuns Turísticos e Culturais}

A falta de informação dos moradores em relação às riquezas da cidade é uma das problemáticas observadas. Seria importante valorizar o turismo regional cultural e histórico, criando rotas turísticas locais, municipais e regionais, podendo assim, valorizar o patrimônio imaterial - cultura caipira, festas religiosas, patrimônio musical e cultural, com parcerias entre municípios vizinhos com incentivos financeiros.

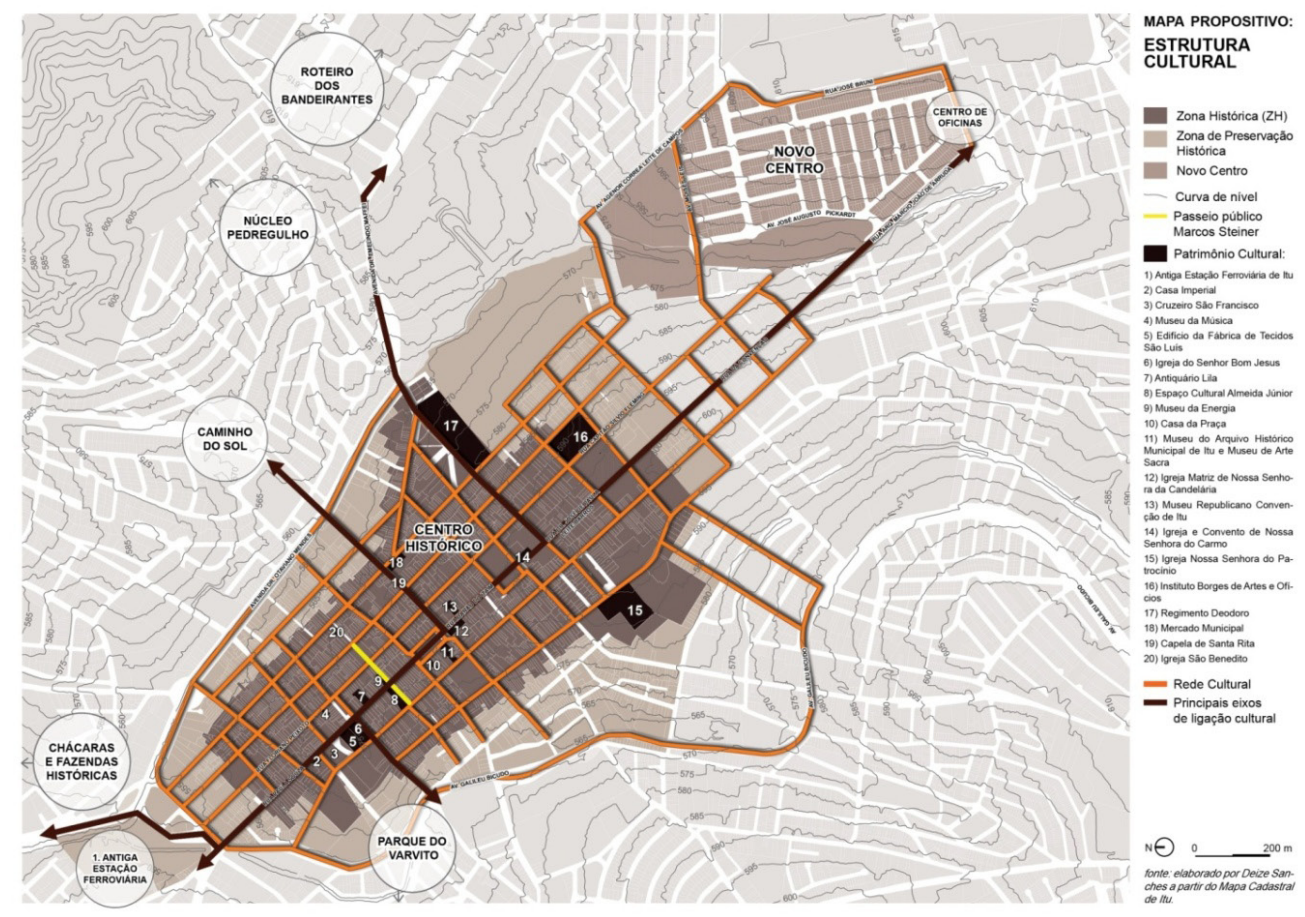

Figura 11 - Mapa propositivo Estrutura Cultural. Fonte: Elaborado pela autora, 2017 


\section{DIRETRIZES - MOBILIDADE URBANA (DTMU) - (Ver Figura 16)}

O Plano de Mobilidade Urbana de Itu visa desenvolver propostas para a infraestrutura local, além de apresentar políticas e ações relacionadas aos deslocamentos na cidade. Em atendimento à Política Nacional de Mobilidade Urbana (Lei nº 12.587/2012), o plano priorizará os modos de deslocamento não motorizados, seguidos pelos modos de transporte coletivo.

De acordo com o Plano de Mobilidade e os levantamentos realizados in loco, serão destacadas ações de melhoria nas principais vias de transporte público, no eixo comercial e histórico, respectivamente Rua Floriano Peixoto e Rua Paula Souza com novos cenários para o caminho do pedestre, do ciclista e do automóvel.

\section{- Instalação do Eixo Comercial Floriano Peixoto (Figura 16)}

A ligação física do Novo Centro com o Centro Histórico será planejada pelas ruas Floriano Peixoto e Capitão Silvio Fleming, numa distância de 2,25 km aproximadamente. Estas vias deverão ser projetadas para serem compartilhadas entre pedestres, bicicletas e automóveis, de acordo com suas necessidades e grau de importância. $O$ projeto deverá seguir a norma de acessibilidade, dando ao pedestre e ao ciclista total segurança e mobilidade de ir e vir para o centro.

\section{- Instalação do Eixo Histórico Paula Souza (Figura 16)}

A Rua Paula Souza e as demais vias que fazem sua continuação, totalizando $3 \mathrm{~km}$, constituirão o eixo histórico de ligação com o Bairro Novo Itu devido ao seu potencial cultural, histórico e arquitetônico, com diversas edificações tombadas - igrejas, museus, residências e praças, concentradas ao longo de 800 metros de toda a extensão do eixo, com diferentes formatações de tipologia urbana. Ela será planejada de forma a conciliar a via do automóvel, a ciclovia e o passeio público para os pedestres com acessibilidade, arborização e mobiliário urbano necessário; proporcionando uma linha de contextualização de valor histórico a percorrer. Assim, o leito carroçável e o passeio público serão redesenhados, dando espaço primeiramente ao pedestre, depois ao ciclista e, por último, ao automóvel. O trecho da Rua Paula Souza que concentra a maior parte dos bens tombados; da Praça do Cruzeiro, esquina com a Rua Barão do Rio Branco até a Praça da Independência, onde se encontra a Igreja e Convento Nossa Senhora do Carmo, será disponibilizado, aos sábados e domingos, para uso exclusivo de pedestres. 
- Instalação do Passeio Público Floriano Peixoto (Figura 12)

O eixo comercial- Rua Floriano Peixoto terá um passeio público proposto entre a Rua Bom Jesus, na Praça do Bom Jesus, e a Rua Maestro Elias Lobo, na Praça da Independência. A intenção é obter um calçadão de 600 metros linear, na área de maior fluxo, facilitando a circulação segura do pedestre e oferecendo um novo espaço público com mobiliário urbano, iluminação e arborização. A conexão entre as praças Bom Jesus e Independência com uma linha verde de árvores de copa larga, ao longo do passeio público, irá colaborar com a criação de um corredor verde importante para reduzir a poluição do ar provocada pelos veículos motorizados na área central.

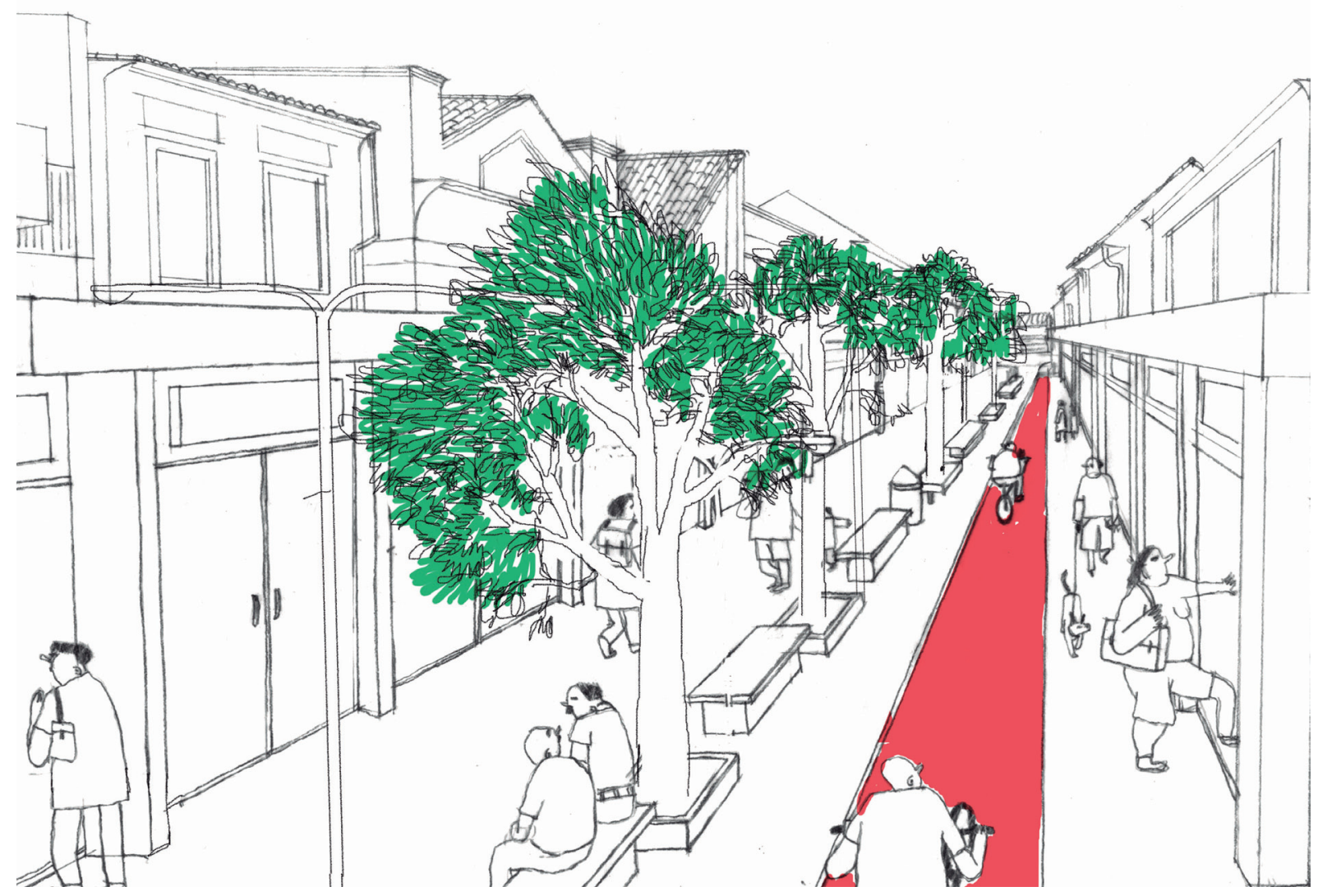

Figura 12 - Desenho ilustrativo do Passeio Público Floriano Peixoto

Fonte: Elaborado pela autora, ilustração de Bruna Ximenes, 2017

- Instalação do Passeio Público Paula Souza (Figura 13)

No segundo e terceiro trechos da Rua Paula Souza, onde há a maior concentração das edificações de valor histórico - museus, igrejas e demais monumentos arquitetônicos - será implantado, aos finais de semana, o Passeio Público Paula Souza, com o intuito de proporcionar maior adesão e conforto aos turistas e moradores no centro histórico. 




Figura 13 - Desenho ilustrativo do Passeio Público Paula Souza

Fonte: Elaborado pela autora, ilustração de Bruna Ximenes, 2017

- Instalação de uma ciclovia - Itu Parque Linear

A proposta do Itu Parque Linear incorpora o desenvolvimento de uma ciclovia às margens dos córregos Taboão e Brochado, cruzando os parques - Ecológico do Taboão e Parque Central (propositivo), e integrando o Bairro Novo Centro ao Centro Histórico. Esta ciclovia irá colaborar com a mobilidade, incentivando o uso de bicicletas para as principais atividades urbanas cotidianas.

\section{- Revitalização das calçadas Históricas Centrais}

As calçadas necessitam de acessibilidade para o pedestre, principalmente para os de mobilidade reduzida. Atualmente, são de mosaico português, o que dificulta o caminhar e o passeio descontraído. É importante o uso de pisos que colaborem com a drenagem natural da água da chuva;

\section{- Renovação e integração do Passeio Público Marcos Steiner}

O Passeio Público Marcos Steiner (3,80 m) será integrado aos Passeios Públicos Paula Souza e Floriano Peixoto, criando um desenho urbano conectado e propiciando 
um espaço público convidativo, com bancos e lixeiras, novas luminárias, novo piso permeável e acessível, canteiros com arborização e fachadas ativas.

\section{- Reurbanização dos Eixos de ligação Centro Histórico e Novo Centro}

Realização das ações estabelecidas pelo PAC (Programa de Aceleração do Crescimento) - reurbanização da Rua Paula Souza, Praça Padre Miguel, Rua Barão de Itaim e Rua Floriano Peixoto com o aterramento da fiação elétrica e outras redes;

\section{- Padronização das calçadas - Novo Centro}

O Bairro Novo Centro possui vias coletoras de 20 metros de largura, com canteiro central, que possibilitam incorporar jardins de chuva ${ }^{4}$ para a drenagem natural das quadras, aproveitando o desnível natural do solo, e implantar calçadas com acessibilidade, equipamentos públicos, arborização e iluminação com fiação subterrânea. $O$ desenho do piso da calçada deverá seguir um único padrão, de acordo com a NBR 9050 de acessibilidade, oferecendo incentivos fiscais aos proprietários de imóveis que padronizarem suas calçadas: faixa de serviço com 0,70 metro, no mínimo, onde serão colocados os mobiliários urbanos; faixa livre para a circulação do pedestre, no mínimo 1,20 metros de largura e não apresentar nenhum desnível, obstáculo ou vegetação, e a faixa de acesso: 1,10 metro com fachadas ativas; podendo receber vegetação e mobiliários urbanos, desde que não impeçam o acesso aos imóveis; totalizando calçadas de 3 metros (Figura 14).



Figura 14 - Corte ilustrativo da via coletora - Novo Centro - Avenida José Bruni Fonte: Elaborado pela autora, 2017

\footnotetext{
4 Jardim de chuva - Canteiro com plantas, formado com o rebaixamento do solo, que coletará a água pluvial através de aberturas delimitadas em seu contorno. Esse solo deve ser tratado para se tornar mais poroso (Cornier e Pellegrino, 2008)
} 


\section{- Instalação de vias de ciclistas - Novo Centro}

As ruas Arquiteto Márcio João de Arruda e José Bruni, e a Avenida Agenor Correa Leite de Campos (vias coletoras) circundam a maior parte do Bairro Itu Novo Centro e possuem condições físicas favoráveis (leito carroçável de 5,5 metros de largura, canteiro central e passeio público de 3 metros) à instalação de uma ciclovia. Esta terá um papel importante porque fará a ligação com a ciclovia proposta da Rua Paula Souza e do Parque Linear, o que irá proporcionar uma melhor conexão entre os bairros (Figura 15).

\section{- Instalação de Sistema Integrado de Transporte Público - Novo Centro}

Deverão ser implantados corredores de BRT nas avenidas arteriais - Av. José Bruni, Dr. Otaviano Pereira Marques e Avenida Galileu Bicudo, integrados com o sistema de transporte público existente - nas vias coletoras e arteriais, o qual deverá aumentar a frequência dos ônibus na hora de pico das vias centrais: Rua do Patrocínio, Rua dos Andradas, Rua Santa Cruz, Rua Santa Rita (Figura 15).

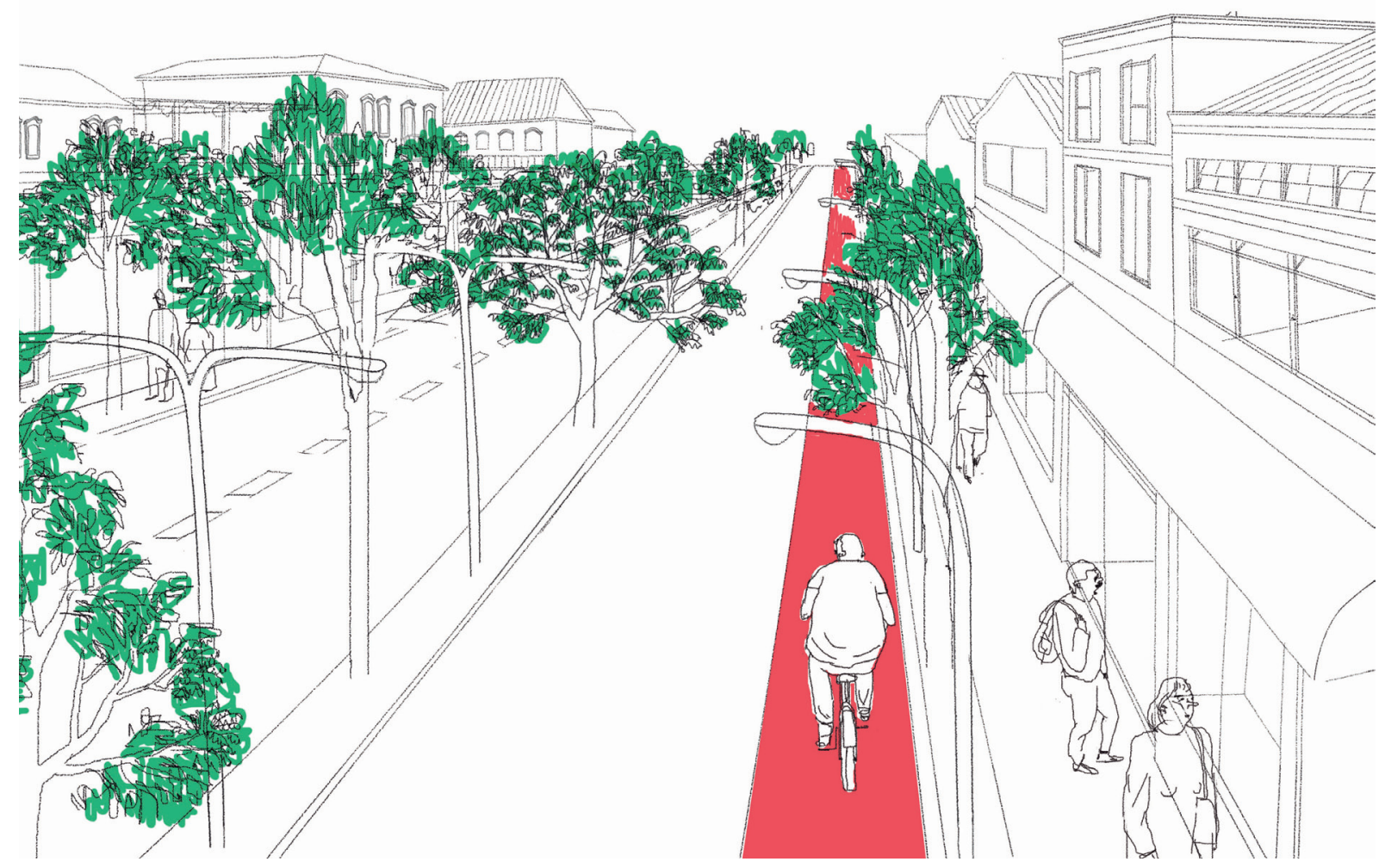

Figura 15 - Desenho ilustrativo da via coletora do Novo Centro - Avenida José Bruni Fonte: Elaborado pela autora, ilustração de Bruna Ximenes, 2017 


\section{- Proposta de quadras abertas - Novo Centro}

As avenidas que margeiam o Bairro Novo Centro, de acordo com o novo zoneamento (ZCC1 - Zona de Corredor Comercial 1), terão uso predominantemente voltado ao comércio. Assim, para fomentar o aumento dos espaços públicos será proposto o desenvolvimento de quadras abertas, onde possa existir o uso de fachadas ativas, maior fruição, permeabilidade das quadras, e maior adensamento das vias marginais, onde o gabarito não exceda a 5 pavimentos com uso misto - escritórios e residências nos pisos superiores e, comércios e serviços, no piso térreo. No miolo das quadras, deverá predominar gabarito de 2 pavimentos. Hoje, temos no bairro a quadra aberta da Prefeitura de Itu como um exemplo a ser seguido.
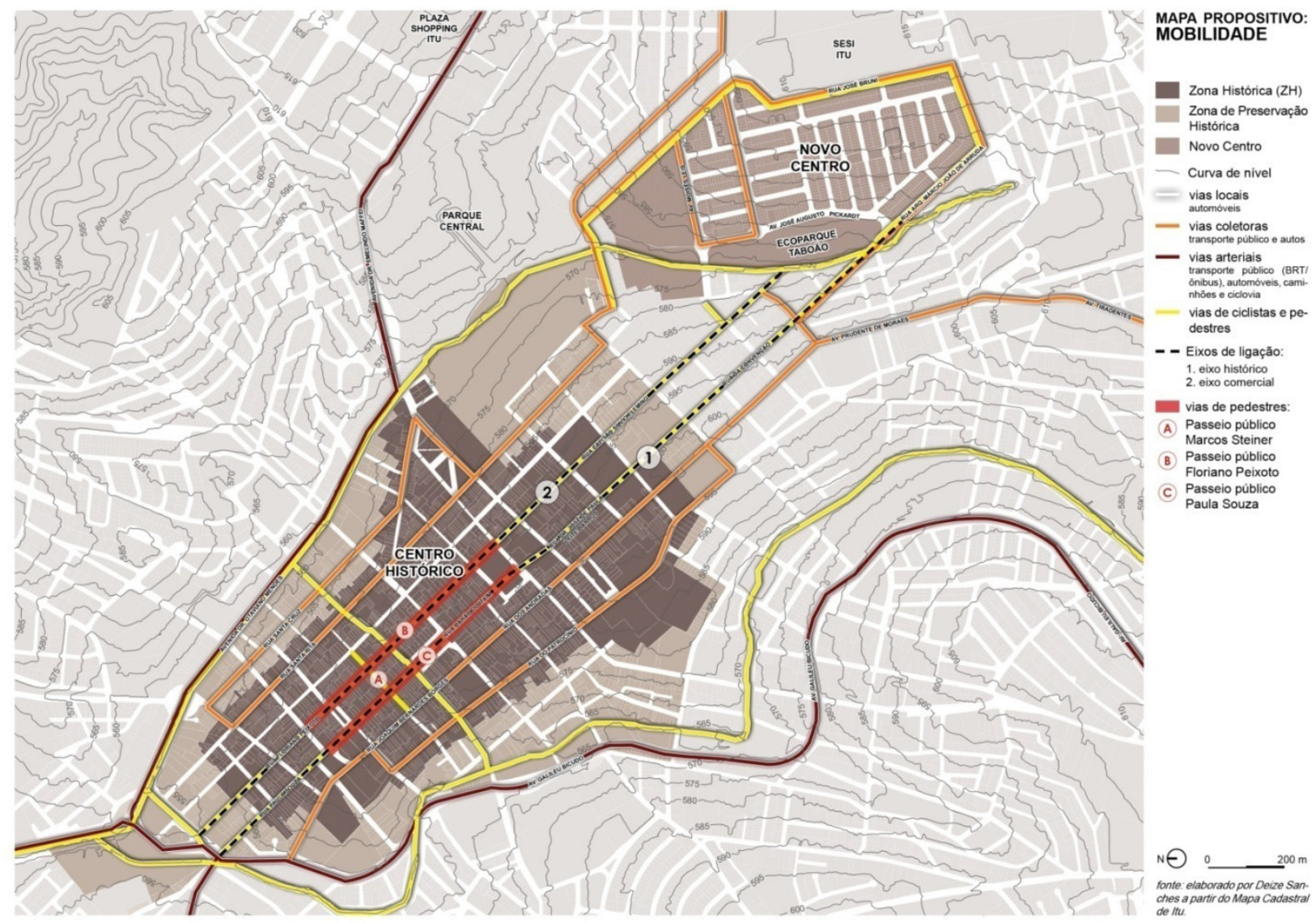

Figura 16 - Mapa propositivo de mobilidade urbana. Fonte: Elaborado pela autora, 2017

\section{DIRETRIZES DE ORDENAMENTO TERRITORIAL - PLANO DIRETOR (DTOT)}

O adensamento no Bairro Novo Centro será uma estratégia de ordenamento territorial que permitirá maiores densidades nos principais eixos de transporte público coletivo, 
qualificará a estrutura urbana por meio de mecanismos como a fruição pública, que incentivará a circulação de pedestres dentro do lote e dinamizará o espaço público da calçada, a fachada ativa; que agregará usos não residenciais no térreo dos edifícios de modo a promover a interação entre o espaço público e privado e contribuirá com a dinamização dos passeios públicos e o alargamento das calçadas, condicionando o recuo frontal das edificações a formar uma calçada com largura mínima de 5 metros, contribuindo para a circulação do pedestre e para a diversidade de padrão social.

A inserção das Zonas de Interesse Social contribuirá para que a população de baixa renda seja integrada às novas áreas de desenvolvimento urbano, possibilitando uma verticalização.

De acordo com os levantamentos realizados, temos como diretrizes de ordenamento territorial:

\section{- Instalação da Área Cultural Vila Deodoro}

A Vila Militar - "Regimento Deodoro", de acordo com o zoneamento vigente está numa ZPH - Zona de Preservação Histórica, terá suas edificações de valor arquitetônica, mantidas e ocupadas com museus e centros culturais com atividades que retomam a memória da Cidade, colaborando com o Projeto oficina - escola.

\section{- Instalação do Parque Central de Itu - 260 km²}

A área verde do Regimento Militar Deodoro, definida como Zona Exclusivamente Residencial 2, terá seu uso alterado para Zona de Preservação Ambiental (ZPA), desenvolvendo nesta área o "Parque Central de Itu" com a intenção de criar um novo espaço de lazer e integração da sociedade, garantindo melhores condições ambientais e de qualidade de vida. O parque estará diretamente conectado ao "Itu Parque Linear".

\section{- Remoção do comércio inadequado do Centro Histórico}

Todo tipo de comércio que não for adequado à necessidade da estrutura local, deverá ser removido para o Novo Centro como incentivo de expansão e integração urbana;

\section{- Fruição pública e uso misto - Novo Bairro}

O Novo Centro terá como diretrizes de ordenamento territorial, o desenho de quadras abertas com fruição pública e uso misto - comércio, serviço e residências em espaços 
multifuncionais para proporcionar um maior adensamento da área. De acordo com o Zoneamento do Plano Diretor de Itu, a área do Novo Centro corresponde à Zona de Predominância Comercial 2, permitindo diversos usos: residenciais unifamiliar e multifamiliar, serviços, comércios, institucionais e condomínios horizontais de residências. Desta forma, possibilita um melhor planejamento de quadras abertas, de forma a sanar as necessidades da população, permitir uma melhor fruição do pedestre e uma maior diversidade de usos.

- Instalação de Novas Áreas Culturais - Novo Centro

Incentivar no planejamento do Novo Centro a existência de equipamentos urbanos culturais, como oficinas, exposições e atividades voltadas aos moradores e turistas em espaços fechados ou abertos.

\section{PROJETO URBANO SUSTENTÁVEL - CENTRO HISTÓRICO E O NOVO CENTRO} (Ver Figuras 17à 21)

Ao longo deste trabalho, constatou-se a importância que a conservação e a manutenção da cobertura vegetal estabelece para a contenção da expansão urbana dispersa, para a conservação e preservação das funções naturais dos recursos naturais e o papel fundamental de integração do patrimônio cultural e turístico ao longo de corredores verdes e parques lineares.

A Estrutura Ecológica é responsável pela melhoria das condições ambientais e sociais, oferecendo melhor qualidade do ar e redução do gás carbônico, recomposição do ciclo natural da água - prevenção contra cheias urbanas, drenagem natural nas áreas urbanas, recomposição do solo exposto por usos inadequados, maior permeabilidade do solo, contribuição para o equilíbrio ecológico - proteção do solo e da água, aumento da biodiversidade, configuração de áreas de lazer e melhor qualidade de vida.

A ligação do Novo Centro com o Centro Histórico a partir da criação das Estruturas Ecológica (EE), Hídrica (EH) e Cultural (EC) irá assegurar as funções ecológicas e as funções de lazer e turismo, proporcionando a valorização e a conservação dos recursos hídricos e do patrimônio cultural, contribuindo com um crescimento urbano mais ordenado e planejado e com a qualidade do espaço urbano e de vida das pessoas. 
A intenção da proposta é valorizar e implantar diferentes usos do solo, criar espaços de convívio público em áreas subutilizadas e sem apropriação da comunidade, oferecer diferentes modais que supram as necessidades de ir e vir de maneira segura, e principalmente, conscientizar a população e dos órgãos públicos, da necessidade da qualidade de vida urbana e da preservação dos recursos naturais, desmotivando assim o desenvolvimento de novos condomínios residenciais fechados e isolados, o que leva ao uso intensivo do automóvel e da especulação imobiliária.

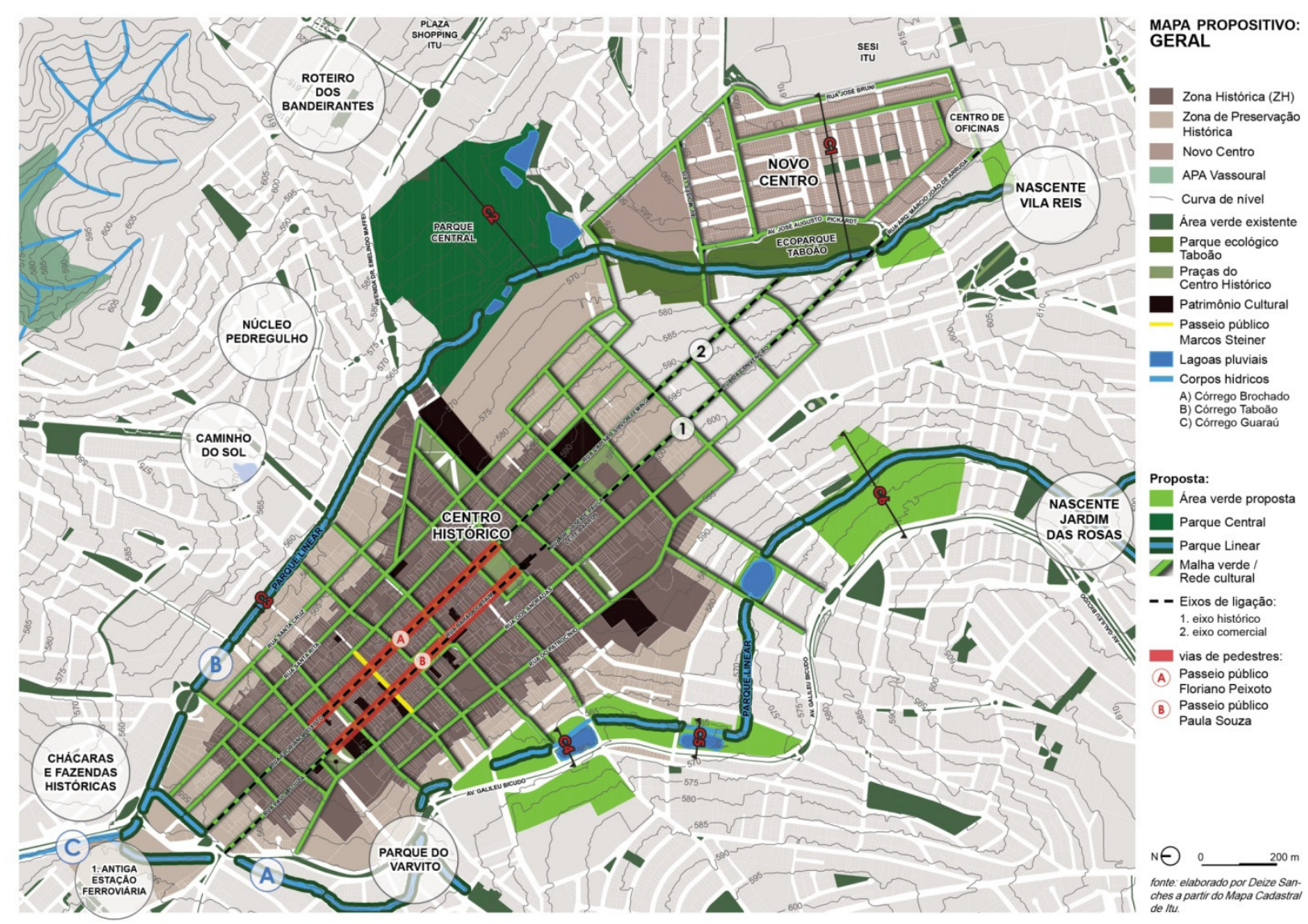

Figura17 - Mapa propositivo geral. Fonte: Elaborado pela autora, 2017



Figura18 - Corte Propositivo 01 - Parque Ecológico Taboão e o Bairro Novo Centro Fonte: Elaborado pela autora, 2017 


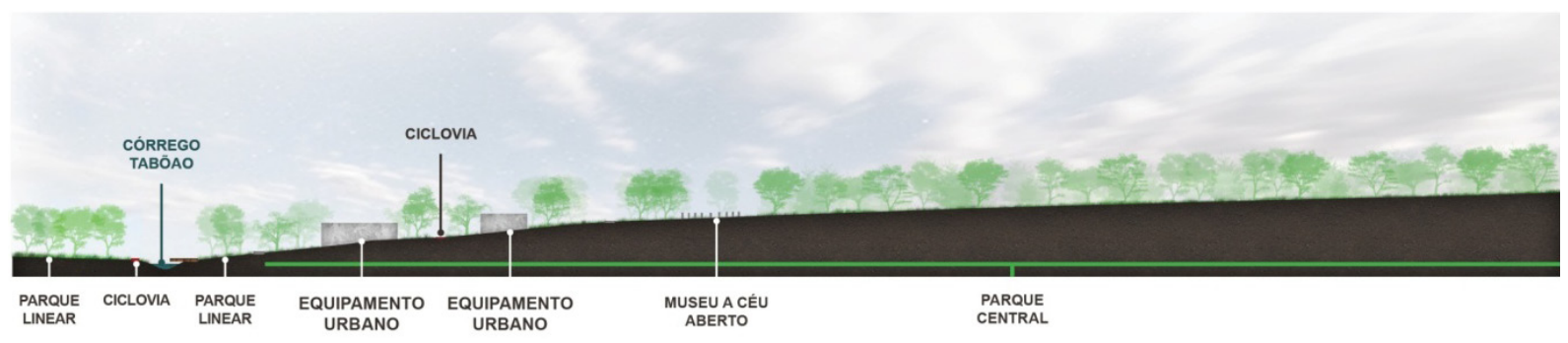

Figura 19 - Corte Propositivo 02 - Conexão do Parque Central e o Parque Linear

Fonte: Elaborado pela autora, 2017



Figura 20 - Corte Propositivo 03 - Parque Linear na Avenida Doutor Otaviano P. Mendes Fonte: Elaborado pela autora, 2017

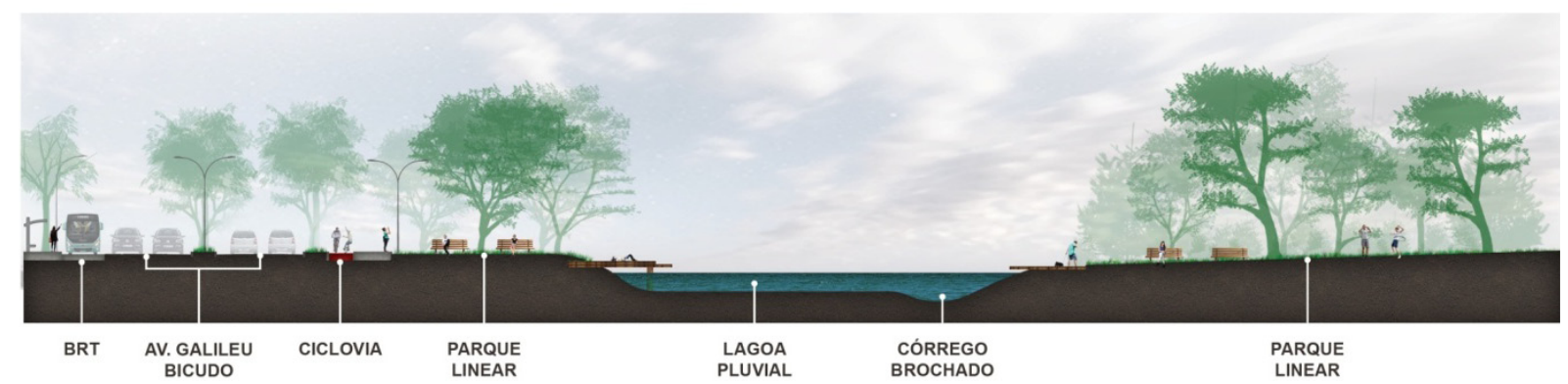

Figura 21 - Corte Propositivo 04 - Parque Linear e a Lagoa Pluvial - Avenida Galileu Bicudo Fonte: Elaborado pela autora, 2017 


\section{CONCLUSÃO}

A pesquisa levantou vários questionamentos: como desenvolver um projeto urbano sustentável, nos dias de hoje, para a cidade de Itu? Em que modelo de cidade os moradores de Itu gostariam de viver? Existe um modelo ideal de cidade?

A elaboração dos eixos estruturadores na cidade de Itu reuniu subsídios para uma análise integral dos requisitos necessários para a realização de um projeto urbano que beneficie tanto moradores e visitantes quanto o ambiente natural transformado o ambiente urbano, sem agredir os recursos naturais existentes, mostrando as deficiências e as potencialidades do local, levando em consideração seus aspectos sociais, ambientais, culturais e econômicos específicos.

Estima-se que, se forem introduzidas as diretrizes propositivas estabelecidas para a cidade de Itu, em um novo Plano Diretor, podemos ter nos próximos 10 anos, uma cidade mais compacta, com mais qualidade de vida e com recursos naturais preservados.

Reprojetar a Ligação do Centro Histórico com o Novo Centro com princípios de sustentabilidade urbana é oferecer uma conexão ambiental, social e cultural entre duas configurações extremas e isoladas da cidade de Itu, e romper com a visão de bairro "ilha" com problemas de mobilidade e de escassez deequipamentos urbanos, entre outros.

A ligação Centro Velho e Novo servirá como uma referência inicial para as demais conexões da cidade, sendo necessário conhecer as características físicas, econômicas, sociais e culturais, as potencialidades, carências e peculiaridades de cada área ou bairro para traçar diretrizes coerentes com a realidade local.

A rede ecológica urbana proposta para a cidade de Itu, reestrutura a paisagem e restaura as funções do ecossistema urbano, tendo como meta tornar os ambientes urbanos mais sustentáveis e resilientes por meio da interação cotidiana das pessoas com a natureza em espaços onde ambas tenham total prioridade.

A cidade de itu foi pensada como um sistema sócio-ecológico por meio de uma visão sistêmica, holística, que consiste em projetar cidades de forma a transformá-las em espaços multifuncionais - que fazem parte de uma rede interligada de fragmentos vegetados, conectados por corredores verdes e azuis, nos quais a biodiversidade protege e melhora as condições das águas. Desta forma, os parques e praças do centro 
histórico de Itu ganham uma importância cada vez maior, oferecendo espaços públicos acessíveis de lazer e permanência, assim como as calçadas verdes, conectando pessoas e lugares. Para isso, Itu precisa apresentar um padrão de desenho urbano mais integrado e reconhecer a relevância dos espaços públicos.

Estes mesmos espaços podem contribuir socialmente ao se transformarem em lugares de fato. A configuração destes locais públicos deve ser produzida com as pessoas, para reunir e compartilhar as visões de vida com os outros; deve ser pensado em espaços funcionais que estabeleçam vínculos com os moradores; e lembrar que tudo deve ser projetado na escala humana porque terá impacto direto na maneira com que as pessoas usam o espaço.

A formulação de diretrizes sustentáveis para a cidade de Itu deverá colaborar com as conexões ambientais, sociais e culturais no espaço urbano, poderá contribuir com a adequação/atualização do plano diretor vigente e com a legislação urbanística, proporcionando uma melhor conservação dos recursos naturais, uma valorização da identidade cultural e uma qualidade de vida.

\section{REFERÊNCIAS BIBLIOGRÁFICAS}

ACSELRAD, Henri. A duração das Cidades. Sustentabilidade e Risco nas Políticas Públicas, DP\&A editora, Rio de Janeiro, RJ, 2001.

ACSELRAD, Henri et al. $\mathbf{O}$ que é Justiça Ambiental. Rio de Janeiro: Editora Garamond, 2008.

AHERN, J. Greenways as a Planning Strategy. Landscape and Urban Planning, vol. 33, Nova York, 1995.

AJONAS, Andréia de Cássia da Silva. Centro e centralidade em Itu- SP / Dissertação de Mestrado - Universidade Estadual Paulista - Faculdade de Ciências e Tecnologia - Presidente Prudente, SP, 2009.

Andréia de Cássia da Silva. Reestruturação Urbana, Centro e Centralidade em Itu - SP. Geografia em Atos, n. 8, v.2. UNESP, Presidente Prudente, 2008. 
FARR, Douglas. Sustainable Urbanism: Urban Design with Nature. Wiley, New Jersey, 2008.

FERREIRA, J. C. Estrutura Ecológica e Corredores Verdes - estratégias territoriais para um futuro urbano sustentável in Pluris $2010-4^{\circ}$ Congresso Luso Brasileiro para o Planejamento Urbano, Regional, Integrado, Sustentável, Faro, 2010.

FORMAN, Richard T. T.;Godron, M. Landscape Ecology. New York, NY: John Wiley \& Sons, 1986.

HERZOG, Cecília Polacow. Cidades para Todos - (re)aprendendo A Conviver Com A Natureza. Editora Mauad Ltda, Rio de Janeiro, 2013.

IBGE.Censo Demográfico 2010, Instituto Brasileiro de Geografia e Estatística, 2010. ITU, Lei Municipal Complementar n 770 de 10 de outubro de 2006, "Plano Diretor Participativo do Município da Estância Turística de Itu”,Itu, 2006.

LEFF. Enrique. Epistemologia Ambiental. Editora Cortez, 2006.

MENEZES, U. T. B. de, ARANTES NETO, A. A., CARVALHO, E. de A., MAGNANI, J. G. C., \&AZEVEDO, P. O. D. A Cidade Como Bem Cultural: Áreas Envoltórias e Outros Dilemas, Equívocos e Alcance da Preservação do Patrimônio Ambiental Urbano. [Debate]. Patrimônio: atualizando o debate. São Paulo: IPHAN, 2006.

OLIVEIRA, Rafael Fabrício de. Patrimônio Histórico-Cultural: Transformações e Usos no Centro Histórico de Itu - SP, Dissertação de Mestrado apresentada ao Programa de Pós-Graduação em Geografia, na área de Organização do Espaço, para a obtenção do título de Mestre em Geografia. Rio Claro - SP, 2012.

RAWLS, John. Uma Teoria da Justiça. $3^{a}$ edição. São Paulo: Martins Fontes, 2008. REIS, Nestor Goulart. Imagens: Vilas e Cidades do Brasil Colonial. São Paulo: Ed. Da Universidade de São Paulo: Imprensa Oficial do Estado, 2001.

RIBEIRO, Rafael Winter. Paisagem Cultural e Patrimônio. Rio de Janeiro: IPHAN/ COPEDOC, 2007. 
RODRIGUES, Murilo Rogério. A Escassez de Água para Abastecimento Público e seus Reflexos Sócioeconômicos no Município de Itu - SP. Dissertação de Mestrado da Faculdade de Filosofia, Letras e Ciências Humanas da Universidade de São Paulo, São Paulo, 2008.

SACHS, Ignacy. Caminhos para o Desenvolvimento Sustentável. Garamond, Rio de Janeiro, 2002.

SANTOS, R. F. Planejamento Ambiental: teoria e prática. São Paulo: Oficina de Textos, 2004.

SAUER, Carl O. A Morfologia da Paisagem. In: CORR A, R.L., ROSENDAHL, Z. (orgs.) Paisagem, tempo e cultura. Rio de Janeiro: EDUERJ, p. 12-74, 1998.

SPIRN, Anne Whiston, O Jardim de Granito: A Natureza no Desenho da Cidade, EDUSP, São Paulo, 1995.

TROPPMAIR, H. Biogeografia e Meio Ambiente. Rio Claro: Divisa, 2004. 